\title{
POLITIK HUKUM MAHKAMAH KONSTITUSI DALAM JUDICIAL REVIEW \\ (SEBUAH PENDEKATAN SOSIOLOGIS)
}

\author{
Murdoko
}

Fakultas Hukum Universitas Widya Mataram

nDalem Mangkubumen KT III/237 Yogyakarta

Murdoko_hk@yahoo.com

\begin{abstract}
Abstrak
Runtuhnya Orde Baru dan diikuti munculnya Reformasi telah merubah sistem politik, sistem hukum, dan sistem ekonomi. Sistem politik dan sistem hukum hampir seluruhnya menyetujui berubah menjadi lebih liberal dengan mengedepankan HAM, tetapi untuk ekonomi terjadi pembelahan, yaitu ikut berubah menjadi liberal sebagaimana dalam politik dan hukum, serta tetap "integralistik" atau kekeluargaan yang mengarah pada sosialisme. Akibatnya terhadap Mahkamah Konstitusi yang bertugas untuk menjaga interpretasi terhadap konstitusi oleh undang-undang memungkinkan terjadinya beberapa model putusan, yaitu model legal, sikap, strategis, dan institusional.
\end{abstract}

Kata Kunci : Reformasi, Kekeluargaan, Liberal, model legal, model sikap, model strategis,dan model institusional.

\begin{abstract}
The collapse of the New Order and the subsequent rise of the Reformation changed the political system, the legal system and the economic system. The political system and legal system almost all agree to change to become more liberal by promoting human rights, but for the economy there is division, which is to change to become liberal as in politics and law, and remain "integralistic" or family that leads to socialism. As a result, the Constitutional Court whose duty is to maintain the interpretation of the constitution by law allows for several models of decisions, namely the legal, attitude, strategic and institutional models.
\end{abstract}

Keywords: Reformation, family, Liberal, legal model, attitude model, strategic model, and institutional model.

\section{A. Pendahuluan}

Runtuhnya rezim otoriter Orde Baru dengan mundurnya Soeharto akibat hantaman krisis ekonomi disertai tekanan-tekanan politik dari dalam dan luar negeri, serta tuntutan mahasiswa di beberapa kota besar Indonesia, menimbulkan euforia untuk segera merombak tatanan kenegaraan dari otokrasi menjadi demokrasi, dari sentralistik menjadi desentralisasi, serta dari represif menjadi liberal ${ }^{1}$. Sehingga jargon perubahan atau reformasi berupa demokratisasi dan

${ }^{1}$ Syamsul Hadi, dkk., mengatakan "tidak pernah dibayangkan oleh kebanyakan orang bahwa gegap gempita reformasi itu justru menjadi ,jembatan emas" bagi penetrasi dan perluasan kepentingan asing dalam ekonomi Indonesia", dalam Syamsul Hadi, dkk., Kudeta Putib, Reformasi dan Peembagaan Kepentingan Asing dalam Ekonomi Indonesia, (Jakarta: Indonesia Berdikari), hlm 1. Donny Gabral Adian, "Pengantar: Politik, Demokrasi, dan Keadilan" dalam Agus Pramusinto \& Erwan Agus Purwanto, Ed., 2012, Indonesia Bergerak, Percik Pemikiran Komunitas Sekip untuk Perubaban,(Yogyakarta: Pustaka Pelajar), hlm 5-8 menyebutnya "minimalisasi kekuasaan negara" di tiga bidang : politik, sosial, dan ekonomi. 
liberalisasi melanda struktur kehidupan berbangsa dan bernegara, terutama di bidang politik, hukum dan perundang-undangan serta ekonomi dengan idiom hak asasi manusia. Bahkan ketentuan tentang Hak Asasi Manusia yang sebelumnya tidak terwadahi secara memadai dalam konstitusi menjadi tertampung secara khusus dalam Pasal 28A sampai 28J UUD 1945 sebagai hasil perubahan. Ujung euforia tersebut adalah berlangsungnya perubahan konstitusi yang tanpa perencanaan "matang" sehingga berlangsung lama dan tanpa "kontrol" sehingga bentuk amandemen tersebut menjadi tumpang tindih atau banyak pengulangan. Bahkan rumusannya pun menimbulkan multi tafsir karena bukan di dasarkan pertimbangan filosofis yang matang sesuai dengan dasar negara yang menjadi landasannya, tetapi merupakan hasil kompromi untuk kepentingan pragmatis berupa memuaskan semua pihak.

Pilihan untuk menempuh jalur reformasi pro-pasar dan mengembangkan demokrasi liberal, maka politik hukum Indonesia cenderung berada dalam tekanan untuk mengembangkan kebebasan dan liberalisasi dalam dua aspek terpenting, yaitu politik dan ekonomi ${ }^{2}$. Politik hukum paska reformasi menampung aspirasi pemerintahan konstitusional yang menempatkan rakyat dan hak asasi manusia ke dalam cita hukum nasional, sekaligus mengakomodasi tuntutan liberalisme yang mendesakkan pasar bebas dan terbuka sebagai perwujudan globalisasi. Arus tersebut masuk melalui usaha-usaha merombak tentang kedaulatan rakyat, pemilihan presiden, dan hak asasi manusia serta Pasal 33 UUD 1945 yang sebelumnya menjadi ideologi ekonomi nasional selama empat puluh tahun, walaupun praktek ekonominya cenderung tidak konsisten ${ }^{3}$.

Perombakan Pasal 33 UUD 1945 dalam perubahan ke-4 telah melalui kontestasi ideologis di antara Tim Ahli Ekonomi Panitia Ad Hoc I Badan Pekerja

${ }^{2}$ Liputan Khusus majalah Gatra edisi 30 November 2011, "Memainkan Pasal Jadi”, dalam Gatra, No. 3, Tahun XVIII (24-30 November 2011), hlm 13 menytakan paling tidak terdapat 25 persen dari Undang-Undang yang dibuat Dewan Perwakilan Rakyat (DPR) ternyata bertentangan dengan konstitusi nasional, yakni UUD 1945. Sehingga mengindikasikan bahwa produk perundang-undangan yang dihasilkan dibuat tanpa pertimbangan konstitusi, namun karena kepentingan yang tidak sejalan dengan kepentingan bangsa dan rakyat sendiri. Dalam "Memainkan Pasal Jadi"

3 Yahya Muhaimin, Bisnis dan Politik : Kebijaksanaan Ekonomi Indonesia 1950-1980, (Jakarta:LP3ES), hlm . Baca pula Richard Robinson, Indonesia : The Rice of Capital, (Sydney: Allen \& Unwin Pty.Ltd.) hlm 25-27. Amandemen tersebut seolah mencerminkan antipati sifat-sifat lama yang "menjerumuskan kedalam kebangkrutan ekonomi dan politik" untuk berubah menjadi hal yang baru, yaitu liberalisasi politik dan ekonomi. 
(PAH I BP) $\mathrm{MPR}^{4}$ yang merumuskan naskah perubahan konstitusi terkait dengan ekonomi. Sebagian anggota Tim Ahli menghendaki agar Pasal 33 UUD 1945 yang menyangkut asas kekeluargaan dan kerakyatan tidak dirubah karena sudah menjadi ideologi bangsa yang dirumuskan para pendiri bangsa. Tim Ahli yang berpandangan seperti ini adalah Mubyarto dan M. Dawam Rahardjo. Sedangkan Tim Ahli lainnya yaitu, Syahrir, Didik J. Rachbini, Sri Adiningsih, dan Sri Mulyani Indrawati menghendaki agar asas itu diubah dan disesuaikan dengan tuntutan reformasi. Alasan yang dipergunakan, bahwa asas kekeluargaan telah dimanipulasi rezim Orde Baru untuk melanggengkan praktek ekonomi oligarkhi sehingga perlu dihilangkan dan diganti dengan asas kemanusiaan atau keadilan.

Secara umum amandemen yang dilakukan dalam bidang ekonomi adalah menghilangkan bagian Penjelasan Pasal 33, yaitu dengan memindahkan menjadi Pasal. Pemindahan penjelasan menjadi pasal tersebut yang kemudian menjadi perdebatan dalam hubungannya dengan reformasi. Sehingga kesepakatannya adalah ayat (1), (2), dan (3) tetap, dan penambahan ayat (4) dan ayat (5) pada pasal 33 UUD 1945 sebagai bentuk kompromi, karena kekhawatiran asas kekeluargaan dan kerakyatan akan dihapus dari Pasal 33 UUD 1945 menjadi tidak jadi dilakukan. Tetapi yang dilakukan adalah menolak untuk mengadopsi bagian Penjelasan Pasal 33 UUD 1945 lama secara utuh, dan hanya memindahkan dan merumuskan kembali kata "demokrasi ekonomi” dalam bagian Penjelasan ke ayat (4) perubahan Pasal 33 UUD 1945 yang baru dengan membubuhkan kata "efisiensi" yang bernuansa pasar dalam sistem perekonomian nasional ${ }^{5}$.

4 Kontestasi tersebut bukan hanya di Panitia Ad Hoc I yang merumuskan rancangan perubahan, tetapi juga suara fraksi dalam usulan dan perdebatan, seperti usulan Fraksi PDI dengan konsep "keberdayagunaan atau efisiensi", dan asas "keadilan dan efisiensi". Fraksi Golkar dengan usulan "kekeluargaan" diganti "kesetaraan dan keadilan". Fraksi PPP dengan usulan "demokrasi ekonomi". Fraksi PDKB dengan usulan "sistem ekonomi pasar sosial" dan "ramah pasar". Fraksi PBB dengan usulan asas "keadilan dan kesetaraan", "daya saing dan kesetaraan", "daya saing dan efisiensi", Fraksi KB dengan usulan "ekonomi pasar yang berkeadilan" dan "mandiri". Fraksi Reformasi dengan usulan asas "daya saing", "keadilan", "efisiensi", dan "kesetaraan antar pelaku ekonomi". Fraksi UG dengan usulan asas "keadilan sosial", "efisiensi" dan "kesetaraan antar pelaku ekonomi”. Tim Penyusun Naskah Komprehensif Proses dan Hasil Perubahan UUD 1945, Naskah Komprehensif Perubahan Undang Undang Dasar Negara Republik Indonesia Tabun 1945, Buku VII, Jakarta: Sekretariat Jendral dan Kepaniteraan Mahkamah Konstitusi), hlm 339-485

5 Kalimat utuh ayat (4) Perekonomian Nasional diselenggarakan berdasar atas demokrasi ekonomi dengan prinsip keadilan, kebersamaan, efisiensi, berkelanjutan, berwawasan lingkungan, kemandirian, serta menjaga keseimbangan, kemajuan, dan kesatuan ekonomi nasional. Ayat (5) Ketentuan lebih lanjut mengenai Pasal ini diatur dalam undang-undang. Rumusan Pasal 33 ayat (4) dan (5)adalah hasil dari rapat ke-4 BP MPR dan kemudian disepakati dalam Rapat Paripurna ke-3 ST MPR 2002 oleh seluruh fraksi di MPR, yaitu Fraksi Partai Golkar, Fraksi PDU, Fraksi PPP, Fraksi PKB, Fraksi Reformasi, Fraksi PBB, Fraksi KKI, Fraksi PDKB, Fraksi UD, Fraksi PDIP, Fraksi Utusan Golongan, maupun Fraksi TNI/Polri melalui Pemandangan Umum, perdebatan di Komisi A, maupun sikap akhir fraksi. Sri Edi 
Pada sisi lain, Undang Undang Dasar Negara Republik Indonesia Tahun 1945 menganut asas-asas "sistem konstitusional" dan "negara berdasarkan atas hukum" yang berarti mengandung makna keharusan adanya suatu tertib hukum, yaitu setiap kaidah hukum harus terkait dan tersusun dalam suatu sistem hukum sehingga tidak mengesampingkan yang lain ${ }^{6}$. Hal ini sebagaimana pendapat Hans Kelsen yang menyatakan bahwa tata hukum adalah suatu sistem norma ${ }^{7}$, dimana peraturan perundang-undangan dari tingkat yang lebih rendah tidak boleh bertentangan dengan peraturan perundang-undangan yang lebih tinggi. Undang Undang Nomor 10 Tahun 2004 tentang Pembentukan Peraturan Perundangundangan $^{8}$ dalam Penjelasan Pasal 7 ayat (5) dikatakan bahwa: "Dalam ketentuan ini yang dimaksud "bierarki” adalah penjenjangan setiap jenis peraturan perundangundangan yang di dasarkan pada asas bahwa peraturan perundang-undangan yang lebih rendah tidak boleh bertentangan dengan peraturan perundang-undangan yang lebih tinggi”. Berdasarkan legal reasoning tersebut maka akan lebih tepat apabila hanya satu lembaga tertentu yang berwenang melakukan pengujian, baik Undang Undang terhadap Undang Undang Dasar maupun peraturan perundang-undangan dibawah Undang Undang terhadap Undang Undang?.

\footnotetext{
Swasono sebagai anggota Fraksi Utusan Golongan menginginkan untuk kembali kepada bunyi aslinya dan tidak sependapat dengan rumusan ayat (4) yang menurutnya akan menimbulkan kontradiksi dan inkonsistensi dan bahkan menimbulkan penafsiran yang tidak jelas, misalnya kata "efisiensi" itu dimaksudkan dalam scope apa?. Sebab kalau hanya efisiensi saja, ekonomi dikejar dengan efisiensi akan terjadi struktur proses produksi yang sangat berubah menjadi kapital intensif dan akan sama sekali membiarkan terjadinya pengangguran. Jadi mengejar efisiensi bisa berarti mengubah struktur produksi menjadi kapital itensif dan mengabaikan labour intensive pada modal. Dengan demikian orang akan mempunyai alasan untuk memberhentikan buruh, mengurangi penggunaan buruh demi efisiensi dan ini juga bisa bertentangan dengan maksud kemandirian. Demi kemandirian, maka justru kadang kadang kita harus mengorbankan efisiensi jangka pendek demi kemandirian kita tidak mengimportal layang. Demi kemandirian kita tidak mengimpor beras murah yang efisien menurut ekonom-ekonom. Dengan kata lain harus ada perkataan efisiensi yang berkemandirian, efisiensi yang berkeadilan, dan selanjutnya.

6 Bagir Manan, Kekuasaan Kebakiman Republik Indonesia, (Bandung: Pusat Penerbitan Universitas LPPM Universitas Islam Bandung, 1995), hlm 46-47. Lihat pula Sri Soemantri, Hak Uji Material di Indonesia, Edisi 2 Cetakan 1 (Bandung: Alumni, 1997), hlm. 82

7 Hans Kelsen, Teori Hukum Murni: Dasar-dasar Ilmu Hukum Normatif sebagai Ilmu Hukum Empirik-Deskriptif, Terj. Somardi, Cet.1 (Bandung: Rimdi Press, 1995), hlm. 112-113

8 Revisi terbaru UU Nomor 12 Tahun 2011

9 Pasal 24C ayat (1) UUD 1945 menyatakan bahwa Mahkamah Konstitusi berwenang mengadili pada tingkat pertama dan terakhir yang putusannya bersifat final untuk menguji UU terhadap UUD dan Pasal 24A yang menyatakan bahwa Mahkamah Agung berwenang untuk menguji terhadap peraturan perundang-undangan di bawah UU terhadap UU. Lihat pula empat kritik Jimly Asshiddiqie terhadap pemisahan hak pengujian, Konsolidasi Naskah UUD 1945 setelah Perubahan Keempat, (Jakarta: Pusat Studi Hukum Tata Negara Fakultas Hukum Universitas Indonesia, 2002) hlm 40-41 serta Fatmawati, Hak Menguji (Toetsingsrecht) yang Dimiliki Hakim dalam Sistem Hukum Indonesia, (Jakarta: RajaGrafindo Persada, 2005), hlm 93-106.
} 
Untuk terciptanya hierarkhi peraturan perundang-undangan ini sekaligus terlaksananya nilai-nilai konstitusi terhadap pembentukan undang-undang, maka diperlukan suatu organ di luar legislative dan eksekutif yang diberi mandat untuk menguji apakah sebuah undang-undang telah berkesesuaian atau tidak dengan konstitusi ${ }^{10}$, sehingga dapat membatalkannya jika berdasarkan penilaian organ tersebut dianggap tidak konstitusional. Organ tersebut untuk di Indonesia disebut sebagai Mahkamah Konstitusi ${ }^{11}$ yang dibentuk berdasarkan ketentuan UUD hasil Amandemen Pasal 24 C yang mengadopsi suatu organ yang disebut Mahkamah Konstitusi. Undang Undang Nomor 24 Tahun 2003 adalah realisasi dari bunyi Pasal 24 C UUD yang menyatakan “ (1) Mahkamah Konstitusi berwenang mengadili pada tingkat pertama dan terakhir yang putusannya bersifat final untuk menguji undang undang terhadap UUD, memutus sengketa kewenangan lembaga negara yang kewenangannya diberikan oleh UUD, memutus pembubaran partai politik dan memutus perselisihan tentang hasil pemilihan umum, dan (2) Mahkamah Konstitusi wajib memberikan putusan atas pendapat DPR mengenai dugaan pelanggaran oleh Presiden dan atau Wakil Presiden menurut UUD”.

\section{B. Telaah Konsep}

\section{Pengujian Undang Undang}

Sampai 15 Pebruari 2014 sudah banyak UU atau beberapa ketentuan dalam UU yang diajukan peninjauan kembali ke Mahkamah Konstitusi ${ }^{12}$, yaitu 923 perkara dengan 258 UU yang diujikan. Dari jumlah tersebut, 137 perkara dikabulkan (14,84\%), 190 perkara ditolak (20,58\%), 157 perkara tidak dapat diterima $(17,01 \%), 52$ perkara ditarik kembali (0,06\%). Diantara putusan Mahkamah Konstitusi tersebut untuk bidang ekonomi antara lain tentang

${ }^{10}$ Ide kewenangan judicial review di Indonesia pertamakali dikemukakan oleh Muhammad Yamin dalam Sidang BPUPK walaupun bukan berbentuk lembaga mandiri tetapi menjadi kewenangan Mahkamah Agung, dalam “Gagasan Bernegara Yamin”, Edisi Khusus Hari Kemerdekaan Tempo, 18-24 Agustus 2014, hlm 120-122

11 Feri Amsari, Perubahan UUD 1945, Perubahan Konstitusi Negara Kesatuan Republik Indonesia Melalui Putusan Mabkamah Konstitusi, Cetakan Kedua, (Jakarta: Rajagrafindo Persada, 2011) hlm 139 menyatakan “...uji konstitusional berbasis salah satunya (selain John Marshall) kepada pemikiran George Jellineck yang mengusulkan agar MA Austria memiliki kewenangan uji konstitusional, tetapi ide dipisahkannya lembaga kekuasaan kehakiman berasal dari Hans Kelsen.

12 Beberapa buku yang sudah membahas Syaiful Bakhri, Migas Untuk Rakyat, Pergulatan Pemikiran Dalam Peradilan Mabkamah Konstitusi, Cetakan I, (Jakarta: Grafindo Khazanah Ilmu, 2013); Martitah, Mabkamah Konstitusi, Dari Negative Legislature ke Positive Legislature, Cetakan I Jakarta: Konpress, 2013). Feri Amsari, op.cit. 
pembatalan UU Nomor 20 Tahun 2002 tentang Ketenagalistrikan oleh Mahkamah Konstitusi serta UU Nomor 22 Tahun 2001 tentang Migas ${ }^{13}$ yang dibatalkan 2 pasal saja. Terhadap putusan tentang UU Ketenagalistrikan tersebut dan pemeriksaan UU Migas, pada saat itu muncul komentar Wakil Kepala Badan Pelaksana Kegiatan Hulu Migas (BP Migas) Kardaya Warnika ${ }^{14}$ mengatakan, jika UU Nomor 22 Tahun 2001 dibatalkan, beberapa badan atau lembaga yang telah dibentuk harus dibubarkan. Selain itu, pelaksanaan otonomi daerah di sektor migas akan batal demi hukum. Pembatalan UU Nomor 22 Tahun 2001 juga membatalkan kontrak migas dengan nilai miliaran dollar AS yang sudah ditandatangani pemerintah dan investor. Hal itu berakibat pada kredibilitas pemerintah dan negara Indonesia di mata para pelaku bisnis, investor, para profesional, dan stakeholder akan merosot. Penerimaan negara dari sektor migas yang selama ini mencapai 30 persen dari total APBN juga akan terganggu. Begitu pula dengan pendapatan pajak yang akan menurun, sehingga pemerintah akan menanggung defisit anggaran.

Ancaman tersebut (baik dikatakan berpengaruh atau tidak berpengaruh), faktanya keputusan Mahkamah Konstitusi berbeda dengan keputusan terhadap UU Ketenagalistrikan yang dibatalkan seluruhnya dengan alasan UU Ketenagalistrikan bertumpu pada dua paradigma, yaitu unbundling (pemecahan ranting usaha) dan kompetisi pengusahaan tenaga listrik. Padahal secara filosofis dan historis kedua undang undang tersebut sama, yaitu terdapat unbundling (pemecahan usaha menjadi BP Migas dan BPH Migas ${ }^{15}$ ) serta kompetisi ${ }^{16}$ dan bahkan UU Ketanagalistrikan yang dibuat lebih belakangan yaitu tahun 2002 daripada UU Migas yang tahun 2001 dibatalkan, maka seharusnya undang undang migas yang dibuat sebelumnya juga dibatalkan total, tetapi kenyataannya hanya beberapa pasal saja yang dibatalkan. Pertimbangan yang lain adalah pembatalan UU Nomor 22 Tahun 2002, mestinya bisa menjadi yurisprudensi. Artinya, secara konstitusi, jika migas dianggap barang

\footnotetext{
13 Buku yang membahasnya natara lain M. Kholid Syeirazi, Di Bawah Bendera Asing, Liberalisasi Industri Migas di Indonesia, Cetakan I, (Jakarta: LP3ES, 2009); Syaiful Bakhri, op.cit.

${ }^{14}$ Kompas, 17 Desember 2004

15 Pasal 5 menyatakan bahwa kegiatan usaha minyak dan gas bumi terdiri atas (1) Kegiatan Usaha Hulu yang mencakup (a) Ekplorasi; (b) Eksploitasi. (2) Kegiatan Usaha Hilir yang mencakup : (a) Pengolahan; ((b) Pengangkutan; (c) Penyimpanan; (d) Niaga

16 Pasal 6 ayat (1) Kegiatan Usaha Hulu sebagaimana dimaksud dalam Pasal 5 angka 1 dilaksanakan dan dikendalikan melalui Kontrak Kerja Sama sebagaimana dimaksud dalam Pasal 1 angka 19 dengan suatu Badan Usaha atau Bentuk Usaha Tetap. Dan Pasal 7 ayat (2) Kegiatan Usaha Hilir sebagaimana dimaksud dalam Pasal 5 angka 2 diselenggarakan melalui mekanisme persaingan usaha yang wajar, sehat, dan transparan.
} 
yang harus dikuasai negara dan undang-undang migas bertentangan dengan hal itu, maka tidak menutup kemungkinan undang undang migas juga bisa dibatalkan. Namun menurut Ketua MK Jimly mengatakan, "bahwa undang-undang dasar tidak menolak kompetisi dan privatisasi, tetapi dalam Undang-Undang Dasar tidak mengenal adanya pasar bebas. Yang pasti, semua dinamika politik harus tunduk pada konstitusi".

\section{Teori Politik Yudisial}

Penelitian tentang hukum dan pengadilan secara umum berkaitan dengan pembuatan keputusan yudisial. Oleh karena itu salah satu bantuan ilmu politik dalam mempelajari hakim dan pengadilan adalah menjelaskan dan memprediksi bagaimana hakim mengambil keputusan dalam tipe-tipe kasus tertentu. Penelitian yang menganalisis pengadilan di Amerika Latin, Eropa, dan bangsa-bangsa di Timur Tengah, serta Australia dan Kanada sekaligus pada rezim demokratis maupun otoriter telah banyak dilakukan, diantaranya oleh Ginsburg ${ }^{17}$, Ginsburg \& Moustafa $^{18}$ serta Shannon Ishiyana Smithey ${ }^{19}$ dan David L.Weiden ${ }^{20}$.

Penelitian tentang pengadilan konstitusional di luar Amerika Serikat menunjukkan bahwa beberapa sistem politik menjadi semakin mengalami "teryudisialisasi" ${ }^{21}$. Maksudnya, bahwa legislator dan eksekutif harus mengantisipasi keputusan-keputusan pengadilan tinggi dan seringkali mengubah kebijakan mereka untuk menghindari kekeliruan. Apalagi dengan adanya perkembangan politik

${ }_{17}$ Ginsburg, T. (2003), Judicial Review in New Democracies: Constitutional Courts in Asia Cases, New York: Cambridge University Press

18 Ginsburg, T. \& Moustafa, T. (Ed.), 2008, Rule by Law: The Politics of Courts in Authoritarian Regimes, Cambridge, UK: Cambridge Univesity Press

19 Shanon Ishiyama Smithey, 2013, "Politik Yudisial Amerika" dalam John T. Ishiyama \& Marijke Breuning, 21 st Century Political Science: A Reference Handbook, terjemahan Ahmad Fedyani Saifudin. Ilmu Politik, Dalam Paradigma Abad ke-21 Sebuah Reformasi Panduan Tematis, Jakarta: Kencana Prenada Media, hlm 1179-1192

20 David L. Weiden, 2013, "Pebandingan Politik Yudisial" dalam John T. Ishiyama \& Marijke Breuning, 21 st Century Political Science: A Reference Handbook, terjemahan Ahmad Fedyani Saifudin. Ilmu Politik, Dalam Paradigma Abad ke-21 Sebuah Reformasi Panduan Tematis, Jakarta: Kencana Prenada Media, hlm 308-321

${ }^{21}$ Tate, C.N., \& Vallinder, T., (Ed), 1995, “The Global Expansion of Judicial Power”, New York: New York University Press, sebagaimana dikutip David L. Weiden, 2013, "Pebandingan Politik Yudisial" dalam John T. Ishiyama \& Marijke Breuning, 21 st Century Political Science: A Reference Handbook, terjemahan Ahmad Fedyani Saifudin. Ilmu Politik, Dalam Paradigma Abad ke-21 Sebuah Reformasi Panduan Tematis, Jakarta: Kencana Prenada Media, hlm 313. Stone, A., 1992, The Birth of Judicial Politics in France: The Constitutional Council in Comparative Perspective, New York: Oxford University Press dikatakan bahwa "pengadilan konstitusional Eropa kini dapat beroperasi sebagai kamar legislatif ketiga", sehingga apabila wakil rakyat di parlemen lemah dan di dominasi oleh eksekutif, maka pengadilan konstitusional menjadi pembuat kebijakan yang lebih efektif daripada parlemen itu sendiri. 
konstitusional supranasional, seperti European Court of Justice, European Court of Human Rights, dan International Court of Justice yang seringkali digunakan sebagai preseden pada kasus-kasus pengadilan konstitusi Eropa. Bahkan diperkuat dengan European Conference yang terdiri dari semua presiden pengadilan tertinggi di Eropa yang bertemu secara teratur dalam konperensi untuk mendiskusikan keputusankeputusan pengadilan mereka masing-masing, sehingga konstitusionalisasi proses politik bergerak dalam batas-batas nasional bahkan ke tingkat supranasional yang mencerminkan peningkatan yudisialisasi politik di Eropa.

\section{Metode Penelitian}

Metode Penelitian yang digunakan adalah metode penelitian hukum normatif melalui pengumpulan data yang sumber utamanya adalah bahan hukum yang berisi aturan-aturan yang bersifat hukum normatif. Data yang diperoleh dan diolah dalam penelitian hukum normatif adalah data sekunder yang berasal dari sumber kepustakaan. Studi kepustakaan dilakukan dengan cara mempelajari literatur, artikel, serta bahan bacaan lainnya yang berkaitan dengan penulisan artikel ini dilakukan melalui penelusuran kepustakaan dan situs-situs internet yang berhubungan dengan penelitian ini.

\section{Pembahasan}

Politik hukum Mahkamah Konstitusi dalam judicial review jika dilihat melalui pendekatan sosiologis dapat dijabarkan dalam tiga model pendekatan sosiologis. David L. Weiden mengidentiifikasi berbagai ahli ilmu politik yang menguji perilaku yudisial para hakim pengadilan banding di luar Amerika serikat dengan menggunakan salah satu dari teori-teori primer pembuatan keputusan yudisial, yaitu model legal, sikeap, dan strategis $^{22}$. Sedangkan Shanon Ishiyama

22 Ibid, hlm 310. Perhatikan pula hasil penelitian Tom Ginsburg, 2003, Judicial Review in New Democracies: Constitutional Courts in Asia Cases, New York: Cambridge University Press yang "menunjukkan bagaimana judicial review melayani kepentingan-kepentingan pelaku politik selama perubahan rezim, dan Ran Hirschi, 2004, Towards Juristocracy: The Origins and Consecquences of The New Constitutionalism, Cambridge, MA: Harvard University Press yang menyebut dengan "Teori Hegemonic Preservation, yaitu pertumbuhan kekuasaan yudisial dapat dijelaskan oleh interaksi antara kepentingan pribadi para aktor politik, elit ekonomi, dan para hakim yang semuanya bekerja untuk menciptakan reformasi konstitusional menurut cara tertentu yang sesuai dengan agenda mereka sendiri”, sebagaimana dikutip David L. Weiden, 2013, "Pebandingan Politik Yudisial" dalam John T. Ishiyama \& Marijke Breuning, 21 st Century Political Science: A Reference Handbook, terjemahan Ahmad Fedyani Saifudin. Ilmu Politik, Dalam Paradigma Abad ke-21 Sebuab Reformasi Panduan Tematis, Jakarta: Kencana Prenada Media, hlm 314. 
Smithey $^{23}$ menyatakan hal yang berbeda, yaitu attitudinal (sikap), strategis, dan institutional.

a. Model Legal

Model legal menurut Segal \& Spaeth ${ }^{24}$ merupakan teori tradisional tentang bagaimana para hakim dalam sistem hukum cammon law memutuskan perkara, yaitu hakim mengambil keputusan berdasarkan merits dari suatu kasus tertentu dengan menginterpretasi fakta-fakta kasus melalui rujukan kepada makna umum dari ketentuan konstitusional atau perundang-undangan, preseden dari kasus-kasus sebelumnya (yurisprudensi), badan legislatif, niat orisinal dari orang yang merancang (draft) hukum atau konstitusional.

Oleh karena itu menurut model legal, hakim tidak menggunakan nilainilai politik atau keberpihakkan pribadi berupa ideologi politik atau preferensi hakim ketika memutuskan perkara, tetapi semata atas dasar faktor-faktor hukum. Tetapi model ini kurang tepat untuk menjelaskan hakim di negara yang sistem hukumnya bukan cammon law, karena para hakim dalam sistem hukum sipil dalam memutuskan tidak berdasar pada preseden atau yurisprudensi kasus-kasus sebelumnya.

\section{b. Model Sikap}

Model Sikap (attitudinal model) menurut Segal \& Spaeth ${ }^{25}$ merupakan representasi perpaduan konsep-konsep kunci dari realisme hukum, ilmu politik, psikologi dan ekonomi. Inti model sikap ini menyatakan bahwa hakim cenderung mengambil keputusan sesuai dengan preferensi politik, sikap, ideologi hakim dan tidak selalu berpedoman pada doktrin, maksud legislatif, atau preseden hukum suatu perkara tertentu yang relevan.

23 Shannon Ishiyama Smithey, 2013, "Politik Yudisial Amerika", dalam John T. Ishiyama \& Marijke Breuning, 21 st Century Political Science: A Reference Handbook, terjemahan Ahmad Fedyani Saifudin. Ilmu Politik, Dalam Paradigma Abad ke-21 Sebuab Reformasi Panduan Tematis, Jakarta: Kencana Prenada Media, hlm 1179-1192

${ }^{24}$ Segal, J.A., \& Spaeth, H.J. 2002, "The Supreme Court and The Attitudinal Model Revisited", Cambridge, UK: Cambridge University Press, sebagaimana dikutip David L. Weiden, 2013, "Pebandingan Politik Yudisial" dalam John T. Ishiyama \& Marijke Breuning, 21 st Century Political Science: A Reference Handbook, terjemahan Ahmad Fedyani Saifudin. Ilmu Politik, Dalam Paradigma Abad ke-21 Sebuab Reformasi Panduan Tematis, Jakarta: Kencana Prenada Media, hlm 310 
Penelitian Spaeth ${ }^{26}$ sebelumnya, yaitu di tahun 1995 menjelaskan mengapa para hakim mengambil keputusan berdasarkan preferensi politik, karena hakim ingin keputusan mereka mencerminkan preferensi kebijaka individualnya. Faktor pendorongnya adalah jabatan yang sudah seumur hidup ${ }^{27}$, kontrol muatan perkara oleh pengadilan ${ }^{28}$, tidak adanya sanksi elektoral atau politis ${ }^{29}$, peradilan tertinggi $^{30}$ maka model sikap dalam pengambilan keputusan perkara adalah atas dasar sikap pribadi, nilai, dan ideologi serta tidak berdasar pada hukum.

\section{c. Model Strategis}

Model strategis mengakui bahwa para hakim akan menentukan pilihan (keputusan) menurut preferensi kebijakan mereka, akan tetapi untuk memaksimalkan preferensi tersebut para hakim juga memperhitungkan suara dari hakim anggota pengadilan yang lain sehingga keputusan akan diambil secara strategis $^{31}$. Artinya hakim tetap mempertimbangkan konteks, karena untuk dapat mengejar tujuan kebijakannya hanya melalui kerjasama dengan yang lain, yaitu meliputi aturan institusional maupun pihak lain agar keputusannya dapat di implementasikan. Misalnya implementasi itu tergantung pada persetujuan pembuat kebijakan lain, seperti polisi, hakim pengadilan, atau dewan sekolah serta perlu juga mempertimbangkan reaksi negatif dari publik.

Resistensi terhadap keputusan yang tidak populer berupa penolakan dan bahkan sampai ke pembalasan langsung, misalnya Konggres membatalkan keputusan hukum, mencabut undang undang tertentu, atau bahkan mengusulkan

26 Segal \& Spaeth, 1995, "The Supreme Court and The Attitudinal Model”, Cambridge, UK: Cambridge University Press, sebagaimana dikutip David L. Weiden, 2013, "Pebandingan Politik Yudisial" dalam John T. Ishiyama \& Marijke Breuning, 21 st Century Political Science: A Reference Handbook, terjemahan Ahmad Fedyani Saifudin. Ilmu Politik, Dalam Paradigma Abad ke-21 Sebuah Reformasi Panduan Tematis, Jakarta: Kencana Prenada Media, hlm 311

27 Karena peradilan Mahkamah Agung merupakan peradilan tertinggi dan hakim nya diangkat untuk seumur hidup sehingga tidak perlu khawatir kehilangan jabatan akibat dari putusan tersebut.

28 Hakim tidak perlu khawatir atas putusannya, karena Mahkamah Agung adalah peradilan terakhir atau tertinggi, sehngga anggota hakim mempunyai diskresi yang hampir total terhadap kasus yang akn diterima untuk judicial review, sehingga kasus-kasus yang tanpa merit atau satu sisi saja akan disingkirkan dan hanya perkara yang mengandung perselisihan murni antara dua posisi yang saling berlawanan secara hukum akan diterima oleh pengadilan.

${ }^{29}$ Hakim diangkat untuk seumur hidup, sehingga dengan putusannya itu tidak bertujuan untuk mencari jabatan politik, sehingga tidak perlu ada kekhawatiran dalam akuntabilitas politik sekaligus kebal terhadap akuntabilitas elektoral karena untuk seumur hidup yang berarti tidak perlu khawatir kehilangan jabatan dalam suatu pemilihan, karena catatan votingnya.

30 Mahkamah Agung adalah puncak piramida, maka tidak ada kemungkinan keputusan Mahkamah Agung mengenai suatu perkara akan di tolak.

${ }^{31}$ David L. Weiden, Ibid, hlm 312 
perubahan untuk mencegah interpretasi konstitusional yang tidak populer menjadi dasar pertimbangan hakim untuk menggunakan model strategis ini. Termasuk misalnya, keputusan yang mengalienasikan publik akan meningkatkan kemungkinan Konggres mengambil langkah-langkh tersebut di atas atau menyebabkan eksekutif tidak melaksanakan keputusan. Dengan demikian, model strategis ${ }^{32}$ ini berargumen bahwa hakim akan mempertimbangkan faktor-faktor eksternal untuk mengantisipasi reaksi yang mungkin timbul sehingga bertindak sedemikian rupa guna meminimalisir serangan balik. Hal ini dilakukan karena hakim harus menyesuaikan tindakannya guna menghindari ancaman eksternal dan untuk mencapai hal-hal yang mungkin dicapai pada situasi itu.

\section{d. Model Institusional}

Model ini sering disebut juga institusionalisme historis ${ }^{33}$ karena fokusnya pada Mahkamah Agung secara keseluruhan, dan tidak seperti model strategis dan sikap yang fokusnya pada tujuan kebijakan dari hakim individual. Sehingga model politik institusional ini kurang fokus pada preferensi kebijakan dari hakim tertentu dan lebih fokus pada karakteristik Mahkamah Agung atau Mahkamah Konstitusi sebagai institusi, relasinya dengan institusi lain dalam sistem politik.

Model institusional menekankan efek dari konteks institusi terhadap keputusan yudisial, dimana hakim mengembangkan keterikatan normatif kepada badan peradilan dan bertindak untuk melayani kekuasaannya. Clayton dan Gillman ${ }^{34}$ menegaskan lebih lanjut bahwa :

"institusi bukan hanya mempengaruhi kemampuan seseorang untuk melakukan hal-hal yang diyakininya; institusi juga merupakan sumber tujuan politik, preferensi dan tujuan lainnya.... Berkenaan dengan politik di Mahkamah Agung, ini berarti bahwa perilaku hakim-hakim dimotivasi bukan hanya berdasarkan kalkulasi peluang dan resiko, tetapi juga berdasarkan kewajiban tugas dan rasa tanggungjawab kepada hukum dan konstitusi, dan oleh komitmen untuk bertindak sebagai hakim ketimbang sebagai legislator atau eksekutif'.

\footnotetext{
32 Shannon Ishiyama Smithey, Ibid, hal 1180

33 Institusional dalam makna lembaga sebagai keseluruhan atau institusi dan relasinya dengan institusi lain dalam sistem politik. Sedangkan historis merupakan penekanan pada penelusuran perubahan aturan institusional dan hasil penyesuaian dalam perilaku yudisial dari waktu ke waktu.

34 Clayton, C.W. \& H. Gillman, 1999, Supreme Court Decision Making: New Institutionalist Approach, Chicago: University of Chicago Press
} 


\section{E. Penutup}

Hakim adalah manusia biasa yang tidak bisa lepas dari pengaruh, Oleh karena itu putusan yang dibuat oleh Hakim sebagai pribadi ataupun majelis hakim adalah cerminan dari sikap hakim yang di dasarkan pengetahuan dan atau kalkulasi-kalkulasi tertentu. Atas dasar hal tersebut, maka putusan hakim tidak selalu konsisten atau sama antar kasus satu dengan yang lain pada konteks yang tidak sama. Secara konseptual bisa diambil melalui tiga model, menggunakan salah satu dari teori-teori primer pembuatan keputusan yudisial, yaitu model legal, sikap, dan stategi 


\section{Daftar Pustaka}

Bagir Manan, Kekuasaan Kehakiman Republik Indonesia, (Bandung: Pusat Penerbitan Universitas LPPM Universitas Islam Bandung, 1995).

Clayton, C.W. \& H. Gillman, 1999, Supreme Court Decision Making: New Institutionalist Approach, Chicago: University of Chicago Press

David L. Weiden, 2013, "Pebandingan Politik Yudisial” dalam John T. Ishiyama \& Marijke Breuning, 21 st Century Political Science: A Reference Handbook, terjemahan Ahmad Fedyani Saifudin. Ilmu Politik, Dalam Paradigma Abad ke-21 Sebuah Reformasi Panduan Tematis, Jakarta: Kencana Prenada Media.

Donny Gabral Adian, "Pengantar: Politik, Demokrasi, dan Keadilan" dalam Agus Pramusinto \& Erwan Agus Purwanto, Ed., 2012, Indonesia Bergerak, Percik Pemikiran Komunitas Sekip untuk Perubahan,(Yogyakarta: Pustaka Pelajar),

Fatmawati, Hak Menguji (Toetsingsrecht) yang Dimiliki Hakim dalam Sistem Hukum Indonesia, (Jakarta: RajaGrafindo Persada, 2005).

Feri Amsari, Perubahan UUD 1945, Perubahan Konstitusi Negara Kesatuan Republike Indonesia Melalui Putusan Mabkamah Konstitusi, Cetakan Kedua, Jakarta: Rajagrafindo Persada, 2011)

Ginsburg, T. \& Moustafa, T. (Ed.), 2008, Rule by Law: The Politics of Courts in Authoritarian Regimes, Cambridge, UK: Cambridge Univesity Press

Ginsburg, T. (2003), Judicial Review in New Democracies: Constitutional Courts in Asia Cases, New York: Cambridge University Press

Hans Kelsen, Teori Hukum Murni: Dasar-dasar Ilmu Hukum Normatif sebagai Ilmu Hukum Empirik-Deskriptif, Terj. Somardi, Cet.1 (Bandung: Rimdi Press, 1995).

Jimly Asshiddiqie, Konsolidasi Naskah UUD 1945 setelab Perubahan Keempat, Jakarta: Pusat Studi Hukum Tata Negara Fakultas Hukum Universitas Indonesia, 2002).

Liputan Khusus majalah Gatra edisi 30 November 2011, "Memainkan Pasal Jadi", dalam Gatra, No. 3, Tahun XVIII (24-30 November 2011),

M. Kholid Syeirazi, Di Bawah Bendera Asing, Liberalisasi Industri Migas di Indonesia, Cetakan I, (Jakarta: LP3ES, 2009.

Maria Farida Indrati, Ilmu Perundang-undangan Dasar-dasar dan Pembentukannya, Ed.1, Cet.1 (Yogyakarta: Kanisius)

Martitah, Mabkamah Konstitusi, Dari Negative Legislature ke Positive Legislature, Cetakan I (Jakarta: Konpress, 2013).

Ran Hirschi, 2004, Towards Juristocracy: The Origins and Consecquences of The New Constitutionalism, Cambridge, MA: Harvard University Press sebagaimana dikutip David L. Weiden, 2013, "Pebandingan Politik Yudisial" dalam John T. Ishiyama \& Marijke Breuning, 21 st Century Political Science: A Reference Handbook, terjemahan Ahmad Fedyani Saifudin. Ilmu Politik, Dalam Paradigma Abad ke-21 Sebuah Reformasi Panduan Tematis, Jakarta: Kencana Prenada Media.

Richard Robinson, Indonesia : The Rice of Capital, (Sydney: Allen \& Unwin Pty.Ltd.) 
Segal, J.A., \& Spaeth, H.J. 2002, "The Supreme Court and The Attitudinal Model Revisited", Cambridge, UK: Cambridge University Press, sebagaimana dikutip David L. Weiden, 2013, "Pebandingan Politik Yudisial" dalam John T. Ishiyama \& Marijke Breuning, 21 st Century Political Science: A Reference Handbook, terjemahan Ahmad Fedyani Saifudin. Ilmu Politik, Dalam Paradigma Abad ke-21 Sebuah Reformasi Panduan Tematis, Jakarta: Kencana Prenada Media.

Shannon Ishiyama Smithey, 2013, "Politik Yudisial Amerika", dalam John T. Ishiyama \& Marijke Breuning, 21 st Century Political Science: A Reference Handbook, terjemahan Ahmad Fedyani Saifudin. Ilmu Politik, Dalam Paradigma Abad ke-21 Sebuah Reformasi Panduan Tematis, Jakarta: Kencana Prenada Media.

Shanon Ishiyama Smithey, 2013, "Politik Yudisial Amerika" dalam John T. Ishiyama \& Marijke Breuning, 21 st Century Political Science: A Reference Handbook, terjemahan Ahmad Fedyani Saifudin. Ilmu Politik, Dalam Paradigma Abad ke-21 Sebuah Reformasi Panduan Tematis, Jakarta: Kencana Prenada Media.

Sri Soemantri, Hak Uji Material di Indonesia, Edisi 2 Cetakan 1 (Bandung: Alumni, 1997).

Stone, A., 1992, The Birth of Judicial Politics in France: The Constitutional Council in Comparative Perspective, New York: Oxford University Press

Syaiful Bakhri, Migas Untuk Rakyat, Pergulatan Pemikiran Dalam Peradilan Mabkamah Konstitusi, Cetakan I, (Jakarta: Grafindo Khazanah Ilmu, 2013);

Syamsul Hadi, dkk., Kudeta Putih, Reformasi dan Peembagaan Kepentingan Asing dalam Ekonomi Indonesia, (Jakarta: Indonesia Berdikari)

Tate, C.N., \& Vallinder, T., (Ed), 1995, “The Global Expansion of Judicial Power”, New York: New York University Press, sebagaimana dikutip David L. Weiden, 2013, "Pebandingan Politik Yudisial" dalam John T. Ishiyama \& Marijke Breuning, 21 st Century Political Science: A Reference Handbook, terjemahan Ahmad Fedyani Saifudin. Ilmu Politik, Dalam Paradigma Abad ke-21 Sebuah Reformasi Panduan Tematis, Jakarta: Kencana Prenada Media.3.

Tempo "Gagasan Bernegara Yamin”, Edisi Khusus Hari Kemerdekaan Tempo, 18-24 Agustus 2014.

Tim Penyusun Naskah Komprehensif Proses dan Hasil Perubahan UUD 1945, Naskah Komprehensif Perubahan Undang Undang Dasar Negara Republik Indonesia Tabun 1945, Buku VII, (Jakarta: Sekretariat Jendral dan Kepaniteraan Mahkamah Konstitusi).

Tom Ginsburg, 2003, Judicial Review in New Democracies: Constitutional Courts in Asia Cases, New York: Cambridge University Press

Yahya Muhaimin, Bisnis dan Politik: Kebijaksanaan Ekonomi Indonesia 1950-1980, (Jakarta:LP3ES). 